Ks. Bogdan Czyżewski

UAM, Poznań

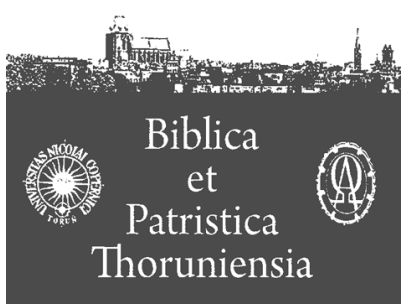

3 (2010)

\title{
Wątki polemiczne w Komentarzu do Listu św. Pawła do Rzymian Pelagiusza
}

Pelagiusz należy bez wątpienia do ciekawych i ciągle zagadkowych postaci Kościoła starożytnego. Jedni uważają go za groźnego heretyka, drudzy widzą w nim ortodoksyjnego pisarza Kościoła zachodniego, jeszcze inni są zdania, że należy podjąć pogłębioną analizę jego pism, aby dowiedzieć się, kim tak naprawdę był Pelagiusz. Na jego temat oraz napisanych przez niego dzieł ukazało się sporo monografii. Pośród nich odnaleźć można zagorzałych przeciwników Pelagiusza a także sporą grupę zwolenników, którzy uważają go za ofiarę błędnej polityki ówczesnego Kościoła ${ }^{1}$.

Nie chcemy wdawać się w żadną z polemik, by udowodnić niewinność bądź też wykazać Pelagiuszowi jakiekolwiek winy. Zamierzeniem niniejszego opracowania jest jedynie zbadanie jego wypowiedzi w odniesieniu do heretyków i reprezentowanych przez nich poglądów, na które powołuje się on w swoim Komentarzu do Listu św. Pawła do Rzymian. Dlaczego zaproponowaliśmy taki właśnie tytuł: Wątki polemiczne? Otóż List św. Pawła do Rzymian, do którego komentarz napisał właśnie Pelagiusz stanowi okazję, by przyjrzeć się, w jaki sposób, przy jego pomocy, zwalcza on herezje swoich czasów. Jest to istotne chociażby z tego powodu, że Corpus Paulinum stanowił dla Ojców Kościoła i pisarzy starożytności chrześcijańskiej ważny oręż w zwalczaniu herezji czy też błędów, jakie pojawiały się w łonie samego Kościoła ${ }^{2}$. Poza tym Pelagiusz jawi się jako wybitny polemista, który potrafił zwięźle i rzeczowo realizować przyjęte cele i założenia

1 Szerzej na ten temat pisze A. Baron, Spór o Pawła, spór o człowieka czy spór o Boga? Refleksje na marginesie kontrowersji pelagiańskiej, w: Pelagiusz, Komentarz do Listu św. Pawła do Rzymian, ŹMT 15, Kraków 1999, s. 12-28. Tam też odnaleźć można podstawową, aczkolwiek bogatą bibliografię dotyczącą samego Pelagiusza i sporów wokół jego osoby (s. 129-167).

2 Taki pogląd wyraził Th. Bruyn. Napisał on, że w IV wieku spory z manichejczykami doprowadziły do swoistego renesansu studiowania Listów św. Pawła. Jest to chociażby przypadek św. Augustyna i Ambrozjastera, którzy w swoich komentarzach do Listów św. Pawła podejmują wiele antymanichejskich wątków (por. Pelagius's Commentary on ST Paul's Epistle to the Romans, Clarendon Press Oxford 1998, s. 14-17). 
bez obrażania swoich przeciwników³ ${ }^{3}$ Użyliśmy słowo „wątki”, ponieważ są to wypowiedzi okazjonalne, całe zaś dzieło Pelagiusza jest interpretacją konkretnej księgi biblijnej, w którym znalazły się także wypowiedzi kierowane pod adresem konkretnych heretyków i reprezentowanej przez nich doktryny.

W swoim Komentarzu do Listu św. Pawła do Rzymian Pelagiusz przypomina błędy niektórych heretyków, ale czyni to w sposób ogólny, bez wdawania się w głębszą i szeroko pojętą polemikę. Zależy mu przede wszystkim na tym, aby przypomnieć swoim czytelnikom, iż teorie niektórych grup chrześcijan, nawet jeżeli opierają je na konkretnych cytatach z Pisma świętego, pozostają sprzeczne z ortodoksyjną nauką. Dlatego też Pelagiusz usiłuje, przy pomocy wypowiedzi św. Pawła zawartych w Liście do Rzymian oraz innych cytatów biblijnych wykazać, że ich nauka jest niezgodna z tym, co głosił Chrystus i Apostoł Narodów.

W Komentarzu Pelagiusza spotykamy, można by rzec, podwójną formę polemiki, chociaż sprowadza się ona zawsze do jednej. W pierwszej wykazuje błędy konkretnym osobom i ich zwolennikom, nazywając ich po imieniu, $\mathrm{w}$ drugiej natomiast chodzi o tych samych, ale już bez powoływania się na ich imiona. Spróbujemy przedstawić polemiczne wątki występujące w Komentarzu Pelagiusza, ale tylko w odniesieniu do heretykó ${ }^{4}$, ponieważ zajmuje się on także oceną wystąpień Żydów przeciwko poganom i pogan przeciwko Żydom, co może stanowić osobne opracowanie.

\section{Ariusz i arianie}

Wśród heretyków wymienianych z imienia i nazwy, najczęściej pojawiają się u Pelagiusza arianie i twórca tej herezji - Ariusz. W komentarzu do słów św. Pawła, gdzie jest mowa o tym, że Jezus Chrystus urodził się „według ciała” (por. Rz 1,3), nasz autor stwierdza, że Apostoł Narodów ugodził tymi słowami w Ariusza. Tłumaczy to w następujący sposób: „Jeśli bowiem uczyniony został pod względem ciała, to oczywiście nie został uczyniony pod względem natury

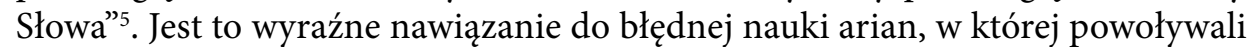
się na inny tekst św. Pawła, z Listu do Galatów 4,4: Gdy jednak nadeszła pełnia

3 Szerzej na ten temat pisze V. Grossi, w: Patrologia III, Marietti 1978, s. 439-458.

4 Należy uczciwie powiedzieć, że używane tutaj słowo „heretyk” było inne w Kościele starożytnym od tego, z którym spotykamy się dzisiaj. Przykładem mogą być chociażby manichejczycy, na których kilkakrotne powołuje się Pelagiusz. Dla niego i innych pisarzy tego okresu byli to heretycy, ponieważ ich nauka pozostawała w wyraźnej sprzeczności z obowiązującą wówczas doktryną Kościoła. Dzisiaj wolimy mówić o nich jako o sekcie bądź też grupie, która popełniała błędy.

$5 \mathrm{~W}$ niniejszym opracowaniu posługujemy się polskim przekładem komentarza Pelagiusza: Pelagiusz, Komentarz do Listu św. Pawła do Rzymian, tłumaczył ks. Arkadiusz Baron, ks. Franciszek Czarnota, Tytus Górski, przypisy oraz indeksy, ks. Arkadiusz Baron, 
czasu, zesłał Bóg Syna swego, zrodzonego $z$ niewiasty, zrodzonego pod Prawem. Zwolennicy wspomnianej herezji uważali, że Chrystus został uczyniony (factus est), nie zaś zrodzony (non generatus), co było jednoznaczne $\mathrm{z}$ błędnym poglądem, iż miał początek ${ }^{6}$.

Kolejny tekst, w którym Pelagiusz pokazuje fałszywe rozumowanie arian odnosi się do słów św. Pawła, gdzie jest mowa o Chrystusie, który wstawia się za ludźmi u Ojca (por. Rz 8,34). Wymienieni heretycy - zdaniem naszego komentatora - uważali, że „z powodu tegoż wstawiennictwa arianie zwykli miotać oszczerstwa twierdząc, że ten, do którego ktoś się wstawia, jest większy od tego, kto się wstawia (por. J 14,28)"7. Był to zatem tak bardzo popularny subordynacjonizm głoszony w ariańskich kręgach, by wykazać niższość Syna od Ojca. Pelagiusz jednak odpowiada zwolennikom Ariusza, że „Bóg nigdy nie zapomina, aby [Mu] zawsze [trzeba było] przypominać o tych, których sam wybrał. Wstawiennictwo zaś /Syna/ polega na tym, że zawsze przedstawia Ojcu i ofiarowuje człowieka, w którego się przyoblekł jako nasz zakładnik, jako prawdziwy, wieczny i najwyższy Kapłan". Pelagiusz używa tutaj zwrotu: hominem, quem suscepit. Jest to zatem ponowne wyraźne zwrócenie uwagi na prawdziwe człowieczeństwo Chrystusa i skierowanie się jednocześnie przeciwko doketom. Mówiąc zaś o Nim jako wiecznym i najwyższym Kapłanie, który ofiarowuje Ojcu człowieka (por. Hbr 6,20), nawiązuje do liturgii eucharystycznej, co znajduje swoje uzasadnienie w Liber sacramentorum Romanae aeclesiae oraz w Sacramentarium Veronense ${ }^{9}$.

O bóstwie Chrystusa mówi Pelagiusz w związku z tekstem św. Pawła: Obraz Chrystusa według ciała, który jest ponad wszystkim, Bóg błogosławiony na wieki ( Rz 9,5). Jest to, według niego, dowód na fałszywy obraz Jezusa, jaki podawali arianie pozbawiając Go prawdziwego bóstwa. Pelagiusz wyjaśnia to zdanie w ten sposób, że Chrystus jest prawdziwym człowiekiem wywodzącym się według ciała $\mathrm{z}$ narodu żydowskiego, jest też prawdziwym Bogiem, co potwierdza Tomasz, kiedy wyznaje przed zmartwychwstałym: Pan mój i Bóg mój (J 20,28). Także sam Chrystus poświadcza to tomaszowe wyznanie: Uwierzyłeś dlatego, ponieważ Mnie ujrzałeś! (J 20,29) ${ }^{10}$.

ŹMT 15, Kraków 1999, s. 169-323. Dalej cytujemy Komentarz Pelagiusza jako RzKom z podaniem podziału na rozdziały i wersety podane przez tłumaczy. RzKom 1,3 C, s. 175-176.

6 Pelagiusz wspomina o błędnej interpretacji tego tekstu przez arian w innym swoim dziele, mianowicie w Libellus fidei 3,4 (PL 45,1717).

7 RzKom 8,34 C, s. 248.

8 RzKom 8,34 C, s. 248-249.

9 Por. Th. De Bruyn, dz. cyt., s. 113; por. także przypis 95 w tekście polskim Komentarza Pelagiusza.

10 Por. RzKom 9,5 B, s. 252. 
$\mathrm{W}$ podobnym tonie wypowiada się Pelagiusz $\mathrm{w}$ jeszcze innym fragmencie swojego Komentarza, mianowicie, kiedy wyjaśnia słowa św. Pawła: Jemu chwała na wieki wieków! Amen (Rz 11,36). Pelagiusz stwierdza, że zdanie to sprzeciwia się arianom, ponieważ jego autor - św. Paweł - wykazuje w nim prawdę, „że jest to jeden i ten sam Bóg, od Którego wszystko [pochodzi] i przez Którego wszystko zostało stworzone"11. Pelagiusz nie waha się też powiedzieć, że Chrystusowi jako Bogu należy się chwała, On bowiem wraz z Ojcem uczestniczył w dziele stworzenia świata i człowieka, na co wskazuje jedność tajemnicy Słowa i Ojca ${ }^{12}$. Tego rodzaju wypowiedzi posiadają wyraźnie antyariańskie zabarwienie, ponieważ autor Komentarza stwierdza, że Syn jest równy Ojcu, czemu zaprzeczali zwolennicy Ariusza.

\section{Fotyn i fotynianie}

Druga grupa, którą imiennie wymienia w swoim Komentarzu Pelagiusz, to Fotyn i jego zwolennicy. Trzy razy odnosi się do nich w sposób bezpośredni. Pierwszy raz, w znanym już tekście św. Pawła Rz 1,3, kiedy jest mowa o pochodzeniu Chrystusa według ciała. W komentarzu do tych słów występuje nie tylko przeciw arianom, o czym już wcześniej była mowa, ale także przeciw Fotynowi. Pelagiusz stwierdza bowiem, że św. Paweł ugodził tutaj w naukę Fotyna ${ }^{13}$, który nie przyznawał Chrystusowi bytu personalnego i nie dostrzegał różnicy osobowej między Ojcem i Synem.

Jeszcze wyraźniej polemizuje z powyższym stwierdzeniem Fotyna i jego zwolenników w komentarzu do zdania św. Pawła: Bóg zesłał swego Syna (Rz 8,3). Pelagiusz uważa, że ta wypowiedź Apostoła Narodów jest „przeciw Fotynowi, który zaprzeczał istnieniu Syna przed [przybraniem] ciała" ${ }^{14}$. Fotynianie, którzy działali także w $\mathrm{V}$ wieku na Zachodzie, nie chcieli bowiem przyjąć prawdy o preegzystencji Słowa ${ }^{15}$.

Raz jeszcze odwołuje się Pelagiusz do fotynian w znanym już tekście, kiedy zwraca się przeciw arianom, by udowodnić prawdziwe bóstwo Chrystusa (por. Rz 9,5). Autor Komentarza wykazuje, że Chrystus pochodzi według ciała z Żydów, natomiast jest też Bogiem na równi z Ojcem, ale Kimś różnym od Niego pod względem osobowym ${ }^{16}$.

11 RzKom 11,36 B, s. 274.

12 Por. tamże.

13 Por. RzKom 1,3 C, s. 175.

14 RzKom 8,3 C, s. 237.

15 Por. M. Simonetti, Studi sullarianesimo, Roma 1965, s. 139.

16 Por. RzKom 9,5 B, s. 252. 


\section{Manichejczycy}

Trzecia grupa, którą wymienia Pelagiusz, to manichejczycy. W jednym z tekstów, zwraca się nie tylko do nich, ale także do arian i fotynian. Chodzi tutaj o cytowaną już wypowiedź św. Pawła, że Obraz Chrystusa według ciała, który jest ponad wszystkim, Bóg błogosławiony na wieki (Rz 9,5). Tym razem Pelagiusz podkreśla nie tylko prawdziwe Bóstwo Chrystusa, ale także Jego człowieczeństwo. W polemice z manichejczykami zacytowany tekst św. Pawła okazał się ważny, gdyż nie przyjmowali oni nauki o Wcieleniu. Uważali bowiem, że Chrystus przyszedł na ziemię bezpośrednio od Ojca i nie posiadał żadnej ludzkiej genealogii ${ }^{17}$. Dlatego też Pelagiusz z takim naciskiem podkreśla, że tekst Pawła „sprzeciwia się [...] manichejczykowi, [...] gdyż /Chrystus/ pochodzi z Żydów, lecz tylko według ciała z nich się wywodzi, jest zaś Bogiem błogosławionym na wieki”"

Dalsza polemika Pelagiusza z manichejczykami dotyczy tej właśnie prawdy, czyli prawdziwego narodzenia Jezusa według ciała oraz natchnionego charakteru Pism Starego Testamentu. Manichejczycy bowiem, podobnie jak gnostycy, odrzucali Stary Testament. Dlatego też Pelagiusz, kiedy powołuje się na zdanie św. Pawła o tym, że o Chrystusie jest już mowa w Starym Testamencie (por. Rz 1,2), odwołuje się do proroka Izajasza $(7,14)$ i z całą stanowczością podkreśla nie tylko znaczenie ale też świętość tych Pism: „już wcześniej Ewangelia została zapowiedziana i przez proroków Boga i w Pismach świętych, oraz że Chrystus co do ciała ma narodzić się z rodu Dawida, to jest z Maryi Dziewicy, jak to zapowiedział Izajasz"19.

W swojej polemice z manichejczykami Pelagiusz wydobywa także z pawłowego tekstu naukę o godności ciała ludzkiego. Chodzi tutaj o zdanie z Listu do Rzymian: Używam ludzkiego sposobu wyrażania się ze względu na słabość waszego ciała. Jak bowiem oddawaliście członki wasze, by służyły nieczystości i nieprawości ku nieprawości, tak teraz oddajcie członki wasze, by służyly sprawiedliwości ku uświęceniu $(\mathrm{Rz} 6,19)$. Pelagiusz uważa, że chociaż „oddaliśmy nasze członki na służbę grzechowi, jednak nie tak, jak twierdzą manichejczycy, iż w naturę ciała wszczepiony jest grzech"20. Człowiek bowiem, spełniając uczynki duchowe, cały staje się duchowy, a zatem i jego ciało jest wtedy duchowe ${ }^{21}$. Wypowiedź ta stała w całkowitej sprzeczności z głoszonym przez manichejczyków fatalizmem, gdzie wskazywali na bezsilność Chrystusa wobec zła, a także z dualizmem, że

\footnotetext{
17 Por. przypis $10 \mathrm{w} R z K o m$, s. 252.

18 RzKom 9,5 B, s. 252.

19 RzKom 1,2 B, s. 175.

20 RzKom 6,19, s. 227.

21 Por. tamże oraz 8,5, s. 239.
} 
zło jest substancjalne człowiek zaś jest do tego stopnia zdeterminowany, iż nie jest w stanie uniknąć grzechu².

Powyższą myśl rozwija Pelagiusz w jeszcze innym tekście, kiedy wyjaśnia zdanie św. Pawła: Ponieważ mądrość ciała wroga jest Bogu: nie jest poddana prawu Bożemu (Rz 8,7). Według Pelagiusza, Apostoł Narodów pokazuje w tej wypowiedzi, że „ciało nie jest wrogie Bogu, jak mówią manichejczycy, lecz zmysł cielesny. Wszystko bowiem, co nie jest poddane, jest wrogie, a każdy kto by chciał się sprzeciwić, niekiedy przekracza również przepisy starego Prawa”23.

Ostatni fragment, w którym Pelagiusz zwraca się przeciwko manichejczykom związany jest z obroną Prawa. Uważali je oni bowiem za coś złego, stąd tė̇ powołuje się na św. Pawła, który uczy, iż Prawo nie jest grzechem lecz prowadzi do jego poznania. Pelagiusz ukazuje postać Chrystusa, który nigdy w żaden sposób nie występował przeciwko Prawu, w przeciwieństwie do manichejczyków, którzy ważą się to czynić ${ }^{24}$.

\section{Marcjon i marcjonici}

Ostatnią wreszcie grupą, z którą otwarcie polemizuje Pelagiusz to marcjonici. W jednym tylko tekście zwraca się do nich bezpośrednio. Okazją ku temu jest fragment Listu św. Pawła, w którym chwali Prawo i podkreśla jego rolę: Prawo wprawdzie jest święte, także przykazanie jest święte, sprawiedliwe i dobre $(\mathrm{Rz} 7,12)$. Pelagiusz w swoim Komentarzu zwraca uwagę na dwie kwestie, które pojawiały się w nauce Marcjona. W pierwszej chodziło o przeciwstawienie Boga Nowego Testamentu Bogu Starego Testamentu. Autor komentarza stwierdza wyraźnie: „Także Bóg często w Starym Testamencie nazywany jest dobrym (por. Ps 72,1), a w Nowym Testamencie - sprawiedliwym, jak mówi Pan: Ojcze sprawiedliwy $(J$ 17,25)"25. Nie można - zdaniem Pelagiusza - oddzielać sprawiedliwości od dobroci, ponieważ Prawo posiada jedną i drugą cechę ${ }^{26}$. Co więcej, Pelagiusz przytacza ze Starego Testamentu określenie Boga, że jest dobry, z Nowego zaś, że jest sprawiedliwy. Tego rodzaju wypowiedź stała w dużej opozycji do marcjonitów, którzy wymienione określenia rozumieli całkowicie inaczej. Dla nich Bóg Starego Testamentu był sprawiedliwy, a zatem okrutny i mściwy, z Nowego zaś dobry i litościwy. Druga kwestia, to dowartościowanie przez autora Komentarza

22 Por. G.I. Bonnier, How Pelagian was Pelagius? An examination of the contentions of Torgny Bohlin, „Studia Patristica” IX,3, Berlin 1966, s. 353-355.

23 RzKom 8,7 A, s. 240.

24 Por. $R z K o m$ 7,7 B, s. 231.

25 RzKom 7,12, s. 233.

26 Por. tamże. 
samego Prawa i Starego Testamentu. Marcjon bowiem i jego uczniowie stanowczo odrzucali cały Stary Testament a zatem i zawarte w nim Prawo ${ }^{27}$.

\section{Heretycy nie wymieniani z imienia}

Pelagiusz prowadzi polemikę z jeszcze innymi heretykami, ale już bez nazywania ich po imieniu. Tak jak w przypadku poprzednio omawianych przedstawicieli błędnowierców tak i teraz autor Komentarza uważa, że św. Paweł najpierw kieruje swoje słowa przeciwko tym, którzy odrzucają Wcielenie i Mękę Chrystusa jako niegodne Boga. Pelagiusz mówi o tym w kontekście słów: Bo ja nie wstydzę się z powodu Ewangelii $(1,16)$. W nawiązaniu do tej wypowiedzi św. Pawła Pelagiusz przekonuje czytelników, iż chrześcijanie nie wstydzą się wierzyć w Chrystusa, który dla nich stał się człowiekiem i umarł na krzyżu. Co więcej, autor Komentarza wyjaśnia, że „dla jednych jest to budzącą odrazę hańbą (por. Ga 3,13), dla drugich zaś znamieniem miłości (pietas) i mocy. Zarazem godzi w heretyków, którzy odrzucają jako niegodne Boga to, że przyoblókł się w człowieka i wydał go na mękę dla zbawienia rodzaju ludzkiego; nie pojmują oni, iż nic nie jest bardziej godne Stwórcy od troski o zbawienie swego stworzenia, zwłaszcza że Sam nie może przez to doznać żadnego uszczerbku dla swej natury, jako że (quasi) nie doświadcza cierpienia"28.

W powyższym tekście mamy do czynienia z kilkoma ważnymi stwierdzeniami. Jest to wypowiedź wyraźnie skierowana przeciwko doketom, ale także tym wszystkim, którzy nie mogli zgodzić się z istnieniem natury ludzkiej u Chrystusa i z Jego męką na drzewie krzyża. Pelagiusz w tym tekście podkreśla dobitnie prawdę o przyjęciu przez Jezusa ciała (carne suscepta) oraz wydaniu go na mękę krzyżową (cruxi fixum), albo też o przyobleczeniu się w człowieka (hominem indueret) i wydaniu go na mękę (passioni traderet). Autorowi Komentarza chodziło przede wszystkim o to, by wskazać na niecierpiętliwość natury boskiej u Chrystusa i na jej niezmienność ${ }^{29}$. $\mathrm{Z}$ drugiej strony Pelagiusz wskazuje na zbawienie człowieka, które dokonało się przez mękę Chrystusa, oraz na jej wartość przebłagalną. Równocześnie stanowi ona podstawę do odpuszczenia grzechów w tajemnicy sakramentu chrztu św. ${ }^{30}$

27 Wyraźnie pisze o tym Tertulian w Contra Marcionem I,19,4; V,13,14, PSP 58, s. 53 i 294.

28 RzKom 1,16 A, s. 179-180. Th. De Bruyn uważa, że Pelagiuszowi chodziło tutaj prawdopodobnie o manichejczyków, marcjonitów i gnostyków (por. dz. cyt., s. 63, przypis 24).

29 Por. J. McW. Dewart, The Christology of the Pelagian Controversy, „Studia Patristica” 17, wyd. E.A. Livingstone, Oxford 1982, s. 1223.

30 Por. przypis 43 do RzKom 1,16, s. 180. 
Pelagiusz powołuje się także na św. Pawła, który, według niego, występuje w swoim Liście przeciwko tym, którzy utrzymują, że wyłącznie ciało grzeszy. Komentując zdanie $\mathrm{Rz}$ 2,9: Na każda duszę człowieka, który dopuszcza się zła, najpierw Żyda a potem Greka, Pelagiusz mówi, że „karą grozi Apostoł duszy ze względu na heretyków, którzy utrzymują, że tylko ciało popełnia występek, zaprzeczają natomiast, iż dusza może grzeszyć" ${ }^{\prime \prime}$. Prawdopodobnie ma tutaj autor Komentarza na myśli manichejczyków, którzy do tego, co materialne odnosili się z ogromną rezerwą, by nie powiedzieć dostrzegali w materii przeszkodę do osiągnięcia zbawienia i niewolę dla duszy. Tymczasem Pelagiusz udowadnia im, że określenie „dusza” odnosi się do całego człowieka ${ }^{32}$. Dowodem tego jest dla niego chociażby tekst $\mathrm{z}$ Rdz 47,27, gdzie jest mowa o tym, że Jakub przybył do Egiptu $\mathrm{z}$ siedemdziesięcioma pięcioma duszami, co oznacza, że przywędrował z taką właśnie ilością ludzi. Mamy zatem do czynienia u Pelagiusza z postrzeganiem człowieka złożonego $\mathrm{z}$ duszy i ciała, i te dwa elementy świadczą o pełnym człowieczeństwie, którego nie wolno pozbawiać materii. Ona bowiem została stworzona przez Boga i została przez Niego także odkupiona.

Kolejny wątek polemiczny odnaleźć można także, zdaniem Pelagiusza, w wypowiedzi św. Pawła odnoszącą się do tych, którzy rozróżniają boga dobrego od boga sprawiedliwego i zaprzeczają, że Bóg karze grzeszników. Komentując zdanie Apostoła Narodów: Bacz więc na dobroć i surowość Bożą (Rz 11,22), Pelagiusz stwierdza, że jest ono „przeciwko tym, którzy twierdzą, że jeden bóg jest sprawiedliwy, a inny [bóg] dobry; a także przeciwko tym, którzy zaprzeczają, że Bóg karze grzeszących"33. Mamy tutaj do czynienia z podwójną polemiką. W pierwszej części tej wypowiedzi odnaleźć można wyraźną aluzję do gnostyków, do Marcjona i jego zwolenników, w drugiej natomiast, kiedy jest mowa o karze za grzechy, chodzi bez wątpienia o manichejczyków.

Jeżeli pokusimy się o podsumowanie tego, co zostało powiedziane na temat polemiki Pelagiusza z heretykami, należy najpierw zaznaczyć, iż dotyczy ona kilku ważnych grup, które jeszcze dawały o sobie znać w Kościele zachodnim w czasach, kiedy żył nasz komentator. Niektóre $\mathrm{z}$ tych osób łatwo można odnaleźć, ponieważ autor Komentarza wymienia je bez wahania, o innych zaś trzeba się domyślać, co nie stanowi większego problemu, ponieważ z kontekstu wypowiedzi wiadomo, kogo miał na myśli.

31 RzKom 2,9 B, s. 191.

32 Pelagiusz pisze o tym także w RzKom 2,10. Nawiązując do tego właśnie tekstu, mówi: „To, co uprzednio nazwał «duszą», tu zwie człowiekiem" (RzKom 2,10, s. 191).

33 RzKom 11,22 A, s. 270. 
Polemika Pelagiusza należy do spokojnych, wyważonych, można by nawet powiedzieć merytorycznych, w której liczy się człowiek. Autor Komentarza nie odnosi się wrogo do swoich adwersarzy, przedstawia zarówno swoje jak i ich poglądy bez emocji i walki słownej. Nie podaje ostatecznych rozwiązań, najważniejszym dla niego dowodem jest konkretny cytat z Pisma świętego, zwłaszcza zaś z Listu św. Pawła do Rzymian. Można nawet nazwać Pelagiusza, w dobrym tego słowa znaczeniu, współczesnym człowiekiem dialogu, który szanuje poglądy swoich przeciwników, ale też rzeczowo i praktycznie przekazuje swoje zdanie. Pelagiusz nie podaje nigdzie gotowych rozwiązań, wskazuje jedynie na błędne rozumienie przez heretyków Osoby Chrystusa i Jego dzieła, które stoją w sprzeczności z tym, co zostało napisane w Piśmie świętym. Ocenę i ostateczny osąd pozostawia czytelnikowi. Nie mamy też w tej polemice do czynienia z wielkimi i ciężkimi sporami natury dogmatycznej.

Ciekawe jest też ustawienie się samego Pelagiusza, który w swoich wypowiedziach tak jakby chciał powiedzieć, że to nie on i jego poglądy, ale św. Paweł oraz Pismo święte stanowią siłę dowodową, a heretycy głosząc swoją naukę sprzeciwiają się Apostołowi i Biblii.

Należy również zaznaczyć, że wypowiedzi polemiczne Pelagiusza mają charakter okazjonalny, aczkolwiek zostały właściwie wplecione w komentowany przez niego tekst. Wydaje się, że w sposób jak najbardziej poprawny wyjaśnia naukę św. Pawła i pokazuje różnym grupom heretyków ich niewłaściwe odczytanie Listu Apostoła Narodów, przez co zniekształcają prawdziwą doktrynę, zwłaszcza odnoszącą się do Chrystusa, zarówno do Jego prawdziwego człowieczeństwa jak i bóstwa.

Na koniec ciśnie się na usta jeszcze jedno ciekawe i ważne stwierdzenie. Taktowany jako heretyk Pelagiusz polemizuje z heretykami i nie uznaje prawdopodobnie siebie za człowieka, który popełniałby jakiekolwiek błędy. Więcej, uważa chyba siebie za pisarza ortodoksyjnego, skoro nie wahał się wytykać błędy doktrynalne innym i traktować swój Komentarz jako zbiór praktycznych wskazówek, które mają służyć całej wspólnocie wiernych. 
Polemical motifs in "The Commentary on St. Paul's Letter to the Romans" by Pelagius

Summary

The paper presents literary analyses concerning heretics and their points of view as discussed by Pelagius in his Commentary on the Letter to the Romans. Pelagius indicates errors of certain heretical groups (Arians, Manicheans, Docetists) related to their wrong reading of the Letter to the Romans. He especially emphasizes the consequences of such a reading present in their distored doctrine of Christ human and divine nature. 